\title{
Cardiovascular Disease in Air Travellers
}

\author{
PETER H. BEIGHTON` AND PETER R. RICHARDS
}

\author{
From Hillingdon Hospital, Uxbridge, and Air Corporations foint Medical Service, London Airport
}

There has been a great increase in civil aviation in the post-war years. In 1966, more than a million passengers a month passed through London Airport. Flying has become so safe and convenient that many disabled people elect to travel by this means. In fact, as many as 5 per cent of passengers on routine scheduled services are suffering from some form of disability, though less than 1 per cent are self-declared invalids.

In the modern jet airliner, the passengers are exposed to a mild degree of hypoxia at ordinary cruising altitudes, due to the reduction in cabin atmospheric pressure. This degree of hypoxia is insufficient to affect healthy adults, but may prove an embarrassment to passengers with impairment of the cardiovascular or respiratory systems. This group accounts for up to 20 per cent of self-declared invalids.

This paper analyses some 25 patients who were admitted to Hillingdon Hospital, a large general hospital near London Airport, during the years 1963, 1964, and 1965. All had collapsed with conditions affecting their cardiovascular systems, either during or immediately after a normal routine flight. The pertinent physiological and environmental factors are discussed, and the routine procedure for handling invalid passengers is described.

\section{Physiological Aspects of Air Travel}

The modern jet engine only operates economically at altitudes above 30,000 feet. To allow aircraft to operate at these heights, it is necessary to pressurize the cabin to an atmospheric pressure sufficient to maintain an environment which is both safe and comfortable for the passengers. The ideal cabin environment would be equivalent to sea-level, but from the aero-engineering point of view this is impracticable, for the aircraft would have to be of

Received June 2, 1967.

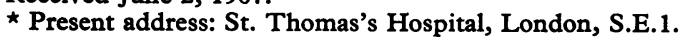

such stout construction that it would be too heavy to operate commercially. The limiting factor is the cabin pressure differential, that is the pressure difference between the inside and outside of the cabin. In modern jet airliners, this is around 8.25 to $8.75 \mathrm{lb}$. per square inch (Bergin, 1967). At cruising altitudes the cabin atmospheric pressure, therefore, corresponds to real altitude of between 5000 and 6000 feet, occasionally reaching 8000 feet (Green, 1965).

Regulations advise that oxygen masks should be worn at cabin altitudes above 10,000 feet, the height that hypoxia first affects the judgement of healthy human beings (Ernsting, 1963). Effects have been shown at lower altitudes (Denison, Ledwith, and Poulton, 1966). From a commercial passenger appeal point of view, oxygen masks are not acceptable. Cabin atmospheric pressures are, therefore, a compromise between passenger comfort and commercial payloads (Peffers, 1958).

At sea-level, the alveolar oxygen tension is 103 $\mathrm{mm}$. Hg. This is reduced to $80 \mathrm{~mm}$. $\mathrm{Hg}$ at 5000 feet, the usual equivalent cabin altitude, and $65 \mathrm{~mm}$. Hg at 8000 feet (Salisbury, Cross, and Barron, 1963). At ordinary cruising altitudes, the alveolar oxygen tension is therefore between 70 and 80 per cent of that at sea-level. The oxygen dissociation curves in healthy adults show that even at $65 \mathrm{~mm}$. $\mathrm{Hg}$ the haemoglobin is still 80 per cent saturated with oxygen (Korner, 1959) (Fig.). The healthy adult is therefore hardly affected at the highest altitude that an aircraft cabin may reach in ordinary conditions, but the invalid, with impairment to the respiratory or cardiovascular system, may be distressed by this degree of hypoxia.

\section{Hospital Admissions}

In the years 1963, 1964, and 1965, 42 patients were admitted to the medical wards of Hillingdon Hospital, after travelling to and from London Airport by air (Beighton, 1967). Of these, 21 patients had 


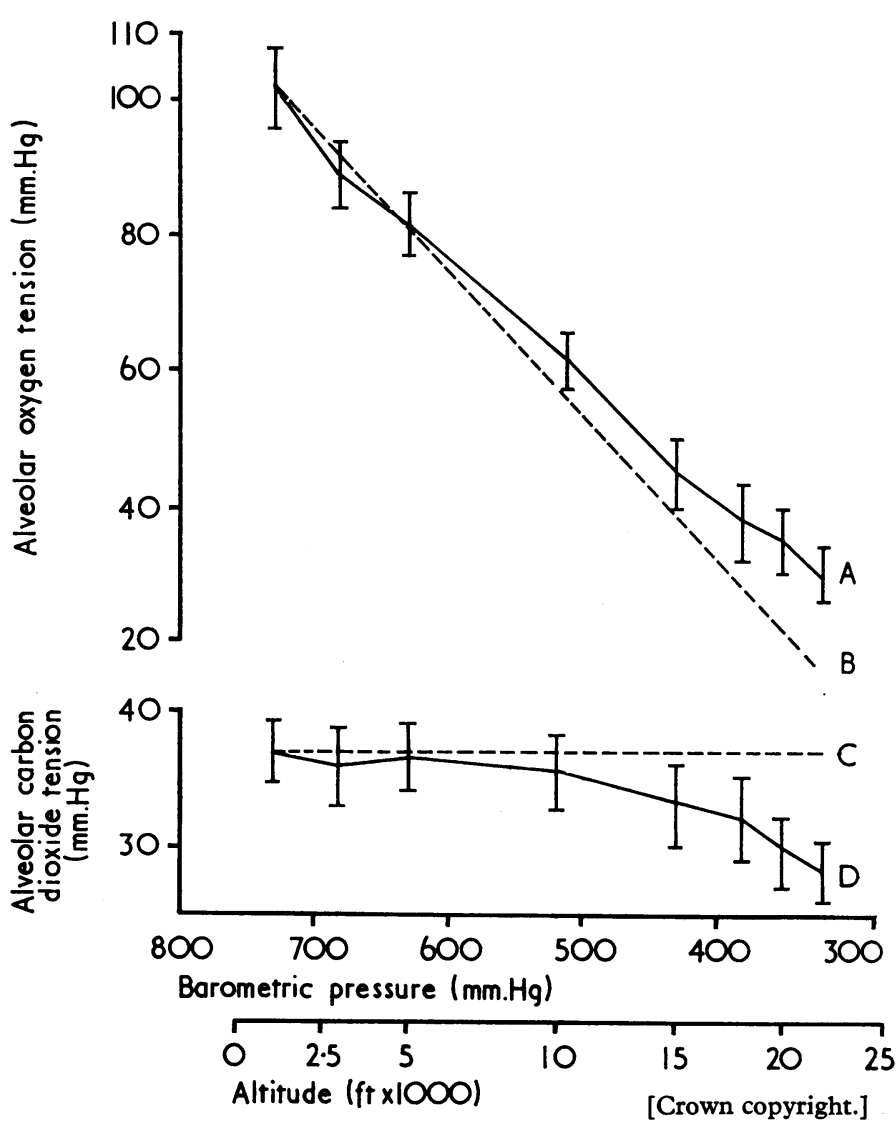

Fig.-The alveolar and carbon dioxide tensions during acute exposure to simulated altitudes while breathing air. Mean values for a series of subjects (with the standard deviation of the mean) are given at each altitude. The broken lines depict the alveolar gas tension which would result if no ventilatory response occurred to anoxia (Boothby, 1944).

illnesses involving the heart, and 4 had illnesses affecting the cerebral circulation. The diagnoses are shown in Table I.

An attempt has been made to relate these happenings to air travel, and the patients have therefore

TABLE I

CARDIOVASCULAR DISEASES DEVELOPING DURING FLIGHT

\begin{tabular}{l|r}
\hline Left ventricular failure & 6 \\
Myocardial infarction & 4 \\
Myocardial insufficiency (angina pectoris) & 6 \\
Cor pulmonale & 2 \\
Paroxysmal tachycardia & 1 \\
Congestive cardiac failure & 1 \\
Dissection of aorta & 1 \\
Cerebrovascular accident & 4 \\
\hline & Total \\
\hline
\end{tabular}

been analysed in terms of the potential predisposing factors occurring during flight. These are hypoxia, which might be a function of cruising altitude, and exhaustion and stress, which are a function of the length of the flight. Significant factors in the patient's past history have been sought, and the use of oxygen during the flight has been recorded.

The jet airliner can climb at over 5000 feet per minute, and the cruising altitude is usually attained within 15 minutes. For this reason, "altitude" has been divided into "cruising", "take-off", "landing", and "ground".

The average length of sector of a long haul airline, for example BOAC, is $\mathbf{3}$ hours $\mathbf{4 0}$ minutes. A flight to Australia would be made up of several such sectors, with breaks of 45 minutes between for refuelling. A short haul operator, for example, BEA, has an average sector of 1 hour 15 minutes. 
TABLE II

PERSONAL AND CLINICAL DETAILS OF ELEVEN PATIENTS DEVELOPING HEART FAILURE DURING FLIGHT



Table II shows the details of the 11 patients with left ventricular failure. None of this group was on anticoagulants, and all were relieved by treatment. Case 5 had an episode of left ventricular failure while flying two months previously. Cases 3 and 5 also had anginal pain at the time of their episode of ventricular failure.

Cases 7 and 8 had cor pulmonale and one of them died. Other conditions shown are paroxysmal tachycardia, dissecting aortic aneurysm, and congestive cardiac failure following myocardial infarction: this latter patient also died.

Four patients had myocardial infarctions. The diagnosis was proven by electrocardiography in
Cases 2 and 4, while Cases 1 and 3 died before records could be obtained. However, the history and clinical picture were sufficiently suggestive in these 2 cases to enable the diagnosis to be made with confidence. The details are shown in Table IIIA.

For the purpose of this paper, myocardial insufficiency has been considered to be a condition due to inadequate oxygenation of the myocardium, characterized by pain, occurring at rest, of anginal quality and distribution, in the absence of any electrocardiographic or serum enzyme changes that might indicate myocardial infarction. The details of the 6 patients are shown in Table IIIB. None were in cardiac failure on admission, and all were relieved

TABLE III

CLINICAL FEATURES OF 10 PATIENTS DEVELOPING MYOCARDIAL INFARCTION AND INSUFFICIENCY DURING AIR TRAVEL




TABLE IV

CLINICAL FEATURES OF CEREBROVASCULAR ATTACKS OCCURRING IN FOUR PASSENGERS DURING AIR TRAVEL

\begin{tabular}{|c|c|c|c|c|c|c|c|c|}
\hline $\begin{array}{l}\text { Case } \\
\text { No. }\end{array}$ & Sex & $\begin{array}{l}\text { Age } \\
(\mathbf{y r} .)\end{array}$ & Nationality & Past history & Underlying cause & Altitude & $\begin{array}{c}\text { Length of } \\
\text { journey (hr.) }\end{array}$ & Outcome \\
\hline 1 & $\mathbf{M}$ & 65 & British & Minor cerebro- & - & Cruising & $<2$ & Died \\
\hline $\begin{array}{l}2 \\
3\end{array}$ & $\begin{array}{l}\mathbf{F} \\
\mathbf{F}\end{array}$ & $\begin{array}{l}61 \\
49\end{array}$ & $\begin{array}{l}\text { American } \\
\text { Australian }\end{array}$ & $\begin{array}{c}\text { vascular attacks } \\
\text { - }\end{array}$ & $\begin{array}{l}\text { Deep vein thrombosis leading } \\
\text { to cerebral embolus via patent } \\
\text { foramen ovale }\end{array}$ & $\begin{array}{l}\text { Cruising } \\
\text { Ground, just } \\
\text { after landing }\end{array}$ & $\frac{6-8}{-}$ & $\begin{array}{l}\text { Relieved } \\
\text { Died }\end{array}$ \\
\hline 4 & $\mathbf{F}$ & 48 & British & 一 & Cerebellar angioma & Cruising & $<2$ & Died \\
\hline
\end{tabular}

by treatment. It is noteworthy that most of these patients were taken ill after the flight.

It is not known if any of this group were on anticoagulants, or if they received oxygen on the aircraft.

Cerebrovascular accidents occurred in 4 patients. These are examined in Table IV.

\section{INVALID PASSENGER HANDLING}

The effects of hypoxia have been known for many years, and many airlines maintain medical consultants to give advice on this problem (Richards, 1967).

TABLE V

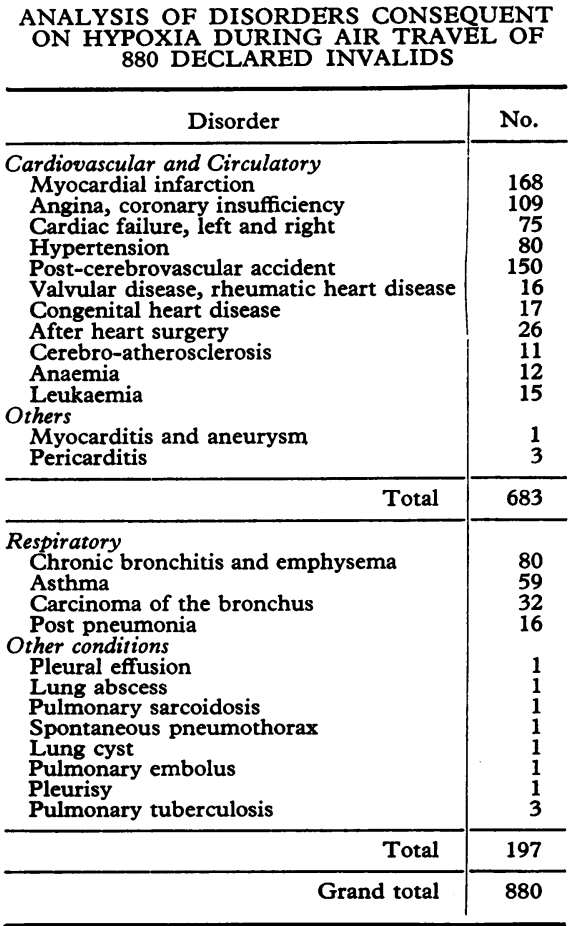

In 1966, for example, BOAC carried more than 5400 declared invalid passengers on whom full consultation and handling had taken place. Among these, $19 \cdot 7$ per cent suffered from disabilities which were likely to be affected by hypoxia. These cases are analysed in Table V.

Where two diagnoses occur in one patient, the major cause of disability or of danger with regard to air travel is given.

\section{Discussion}

The Air Corporations Joint Medical Service acts in the following way with regard to advising and handling invalid passengers for BEA and BOAC.

Authorization. Each passenger is assessed for his fitness to travel, by consultation with his medical practitioner. The most opportune moment must be chosen for his flight, and if his condition contraindicates air travel, he will be advised to delay until the condition is controlled or until he is out of danger. Each case is assessed on its individual merits and medical evacuations or urgent treatment missions are, of course, never refused.

Special Recommendations and Assistance. The Medical Department can ease the passenger flow through the documentation at Immigration and Customs. Anxiety of the invalid is allayed by the Medical Department, who take over this responsibility. The invalid can be spared physical effort by such factors as transport to and from the aircraft, assistance up the aircraft steps, and special seating arrangements. Special assistance in the form of medical escorts, availability of invalid oxygen sets, advice on diets, special seating, stretchers, and stopover facilities, are all arranged by the A.C.J.M.S. (Bergin, 1967). A few of the arrangements are mentioned, but the three most important are, without doubt, the consultation between the medical practitioner and the initial authorization, and the allayment of anxiety by the A.C.J.M.S. taking over some of the documentation of the passenger, and 
sparing him the physical exertion of the journey from the departure building to the aircraft stand, by providing transport right up to the plane.

Unnotified Invalids. Apart from the large number of passengers who are self-declared invalids, and on whom full consultation and handling arrangements can be made, there is another large group who present as invalids after their travels have started. In BOAC, this group exceeded 2200 in 1966, and it is among this group that most of the cases of collapse and casualties have occurred. No provision can be made for these passengers until they draw attention to themselves by demanding attention en route. Of 4400 declared invalids, only 288, that is 5 per cent, required any form of attention on the journey. It must be remembered that this group contains nearly all the very seriously ill patients, including 175 on stretchers.

Of the 9 deaths described in this article, only one was an "authorized", declared patient, a stretcher case known to be suffering from acute coronary insufficiency. He had been accepted for travel between the Middle East and South America, accompanied by his physician. His condition deteriorated so much between Beirut and London that it was decided he was unfit to continue, and he died shortly after his admission to hospital.

Passengers in jet aircraft are exposed to a degree of hypoxia. This is harmless in fit people. However, it may well be the precipitating factor in causing further deterioration in those people with established cardiovascular disease. The cases described in this paper could all be due to chance. On the other hand, it is likely that hypoxia has played a part.

From the economic point of view, it is impossible to improve the degree of pressurization. The alternative, therefore, is surely that more use should be made of the invalid passenger handling services. There may well be justification for the prophylactic use of oxygen in those groups of passengers especially at risk. The airline medical services emphasize the importance of hypoxia during the instruction of their cabin staff in passenger care.

Myocardial insufficiency seemed to occur on the the ground, rather than in the air. Stress and exertion are the obvious precipitating factors in these cases. In common with other forms of long distance travel, the period after leaving the aircraft involves a certain amount of stress and effort, culminating in collecting baggage, and having it examined in the Customs Hall. This period is probably more stressful than has previously been recognized, and further modification of the system would doubtless be beneficial (Abelson and Star, 1966).
The stasis of a long journey, combined with pressure from the aircraft seat at the back of the legs and the hypoxia, together provide an ideal climate for precipitating deep vein thrombosis. It is almost impossible to estimate the true incidence of deep vein thrombosis, as in many cases the symptoms are minimal and only occur when the flight is over. One case is described of a fatal cerebral embolism, due to a clot arising from a deep vein, and passing through a patent foramen ovale. With these considerations in mind, it is worth while to induce those most at risk, however comfortable, to take a prophylactic stroll to the washroom along the aircraft gangway, for the benefit of the exercise, from time to time during a lengthy flight.

\section{SUMMARY}

The physiological effects of the environment in modern commercial passenger aircraft are described with special reference to the reduced atmospheric pressure of the cabin at normal cruising altitudes, and the ensuing mild degree of hypoxia experienced by passengers on routine services.

The results of a survey of 42 cases of cardiovascular illness occurring in air travellers who were admitted. to hospital after their flight, are presented. The association between air travel and these illnesses is discussed.

The airlines medical services' methods of handling invalid passengers are described and, in the light of this survey, further suggestions are made. The results of the survey suggest that the mild hypoxia experienced by passengers travelling in modern aircraft, though harmless to the healthy passenger, may adversely affect those with impairment of their cardiovascular systems.

We would like to thank Dr. G. Blanshard, Consultant Physician of Hillingdon Hospital, for his help in the preparation of this paper, and Dr. J. Graham Taylor, Director of Medical Services at BOAC/BEA, for giving permission to publish.

\section{REFERENCES}

Abelson, L. C., and Star, L. D. (1966). A survey of pre flight, in flight and post flight deaths at J. F. Kennedy International Airport. XV International Congress of Aviation and Space Medicine, Prague.

Beighton, P. H. (1967). Medical hazards of air travel. Practitioner, 198, 668.

Bergin, K. G. (1967). Transport of invalids by air. Brit. med. F., 3, 539.

Denison, D. M., Ledwith, F., and Poulton, E. C. (1966). Complex reaction times at simulated cabin altitudes of 5,000 feet and 8,000 feet. Aerospace Med., 37, 1010. 
Ernsting, J. (1963). The ideal relationship between inspired oxygen concentration and cabin altitude. Aerospace Med., 34, 991.

Green, I. D. (1965). The circulation in anoxia. In A Textbook of Aviation Physiology, p. 264. Ed. by J. A. Gillies. Pergamon Press, Oxford.

Korner, P. I. (1959). Circulatory adaptations in hypoxia. Physiol. Rev., 39, 687.
Peffers, A. S. R. (1958). The Effects of fet Air Travel on the Respiratory and Cardiovascular System. British Overseas Airways Corporation, London.

Richards, P. R. (1967). Hypoxia in modern pressurized jet aircraft. Practitioner, 198, 664.

Salisbury, P. F., Cross, C. E., and Barron, C. I. (1963). Circulatory effects of arterial hypoxia. Aerospace Med., 34, 935. 